University of Denver

Digital Commons @ DU

Religious Studies: Faculty Scholarship

Religious Studies

Winter 2018

\title{
Locating Palestine's Summer Residence: Mandate Tourism and National Identity
}

Andrea L. Stanton

University of Denver, andrea.stanton@du.edu

Follow this and additional works at: https://digitalcommons.du.edu/religious_studies_faculty

Part of the Islamic Studies Commons, and the Islamic World and Near East History Commons

\section{Recommended Citation}

Stanton, A. L. (2018). Locating Palestine's summer residence: Mandate tourism and national identity. Journal of Palestine Studies, 47(2), 44-62. https://doi.org/10.1525/jps.2018.47.2.44

\section{(4) (9)}

This work is licensed under a Creative Commons Attribution-Noncommercial 4.0 License This Article is brought to you for free and open access by the Religious Studies at Digital Commons @ DU. It has been accepted for inclusion in Religious Studies: Faculty Scholarship by an authorized administrator of Digital Commons@DU. For more information, please contact jennifer.cox@du.edu,dig-commons@du.edu. 


\section{Locating Palestine's Summer Residence: Mandate Tourism and National Identity}

\section{Comments}

Original publication may be viewed at https://doi.org/10.1525/jps.2018.47.2.44

Publication Statement

Copyright held by the author or publisher. User is responsible for all copyright compliance. 


\section{Locating Palestine's Summer Residence: Mandate Tourism and National Idẹntity}

ANDREA L. STANTON

The carving up of the Ottoman Levant into British and French Mandates after World War I introduced new realities for the inhabitants of the region. This article uses Lebanese tourism and the promotion of Lebanon as a tourist destination to Palestinians of all religious backgrounds as a case study to investigate the challenges and potentials of the new Mandate structures. Using Palestinian government archives and newspapers, it examines how Lebanon was marketed to Palestinian vacationers. It concludes by suggesting that tourism, with its mixture of private and government sector interests, serves as a key node for observing the messy process of relational identities when two sets of neighbors worked to reframe themselves in national terms.

SOMEONE SITTING DOWn TO READ a copy of Jaffa-based Falastin in May 1935 would have seen the usual run of advertisements: for His Master's Voice radios, sold by Boutagy and Sons; for the lottery; for film showings at various cinemas; and for items such as imported shoe polish or soap. ${ }^{1}$ By June, however, that same reader would have started to see a new series of advertisements, encouraging them to think of the summer and, more specifically, of spending the summer in Lebanon. Some advertisements-like that of Haifa's Hotel Petra-promoted travel-related enterprises within Palestine. ${ }^{2}$ But the bulk of the summer travel advertisements focused on particular establishments in Lebanon such as the Grand Hotel Kadri in Zahle, which promised fresh air and relaxation, as well as tennis, an orchestra, radio, cinema, a dance hall, and "every means of relaxation." 3 Other advertisements focused on Lebanon as a destination. "All to Lebanon," one proclaimed in English, showing a series of birds flying in staggered formation each with a placard hanging from its beak designating a Palestinian city: Jerusalem, Tel Aviv, Haifa, Jaffa, Nazareth. Lebanon, the ad declared in Arabic, was "Palestine's Summer Residence," where readers were urged to go and renew their health. " "Relaxation, Health, and Economy," proclaimed another ad with an illustration of a grove of cedars and a bellman toting valises and a travel trunk. ${ }^{5}$ The images were appealing, and the text added convivial descriptions of the scenic, yet modern, summer vacation one could enjoy in the mountains of Lebanon. But how significant were these advertisements as a marker of Palestinian tourist travel to Lebanon? And what can this kind of regional tourism tell us about emerging relationships between two newly defined national communities during the Mandate period?

Journal of Palestine Studies Vol. XLVII, No. 2 (Winter 2018), p. 44, ISSN: 0377-919X; electronic ISSN: 1533-8614. () 2018 by the Institute for Palestine Studies. All rights reserved. Please direct all requests for permission to photocopy or reproduce article content through the University of California Press's Reprints and Permissions web page, http://www.ucpress.edu/journals.php?p=reprints. DOI: https://doi.org/10.1525/jps.2018.47.2.44. 


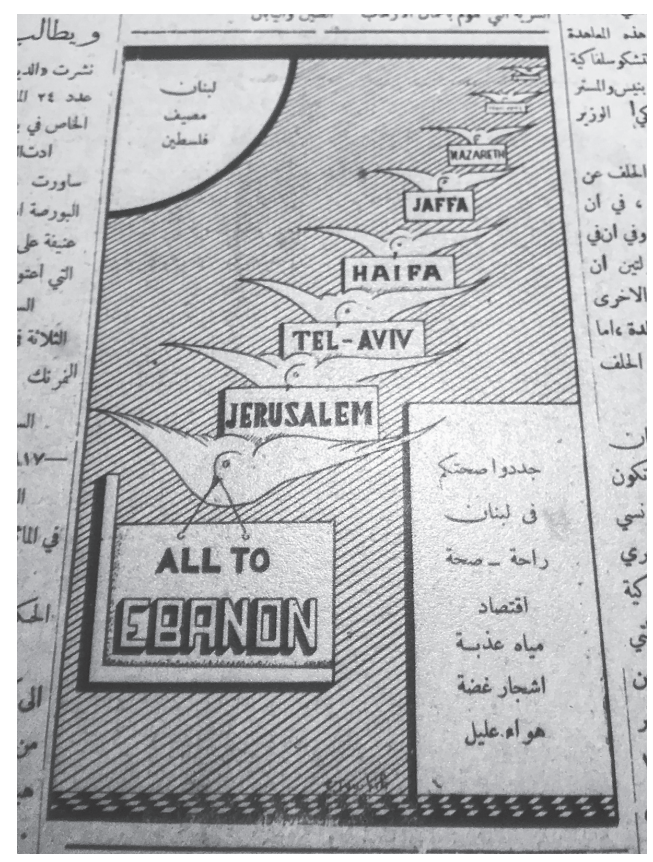

"Lebanon: Palestine's summer residence" advertisement, Falastin, 20 June 1935, p. 7. (American University of Beirut microfilm collection)

The establishment of Mandate territories under British and French governance in the Arab provinces of the former Ottoman Empire produced numerous ruptures in the lives of their inhabitants. The process did not take place overnight: the League of Nations formally assigned Palestine and Lebanon as Mandate territories to Britain and France (the latter as part of a broader Syrian Mandate) only in September 1923, five years after the defeat of the Ottomans in World War I. But what was in effect British and French control on the ground-both administrative and military-meant that political, economic, and cultural shifts began almost immediately after the war, with old structures and practices being erased and new ones introduced. The shift from province or sanjak to Mandate state not only elevated regional centers like Beirut and Damascus to the status of national capital, but it also entailed the issuance of new currencies and postal stamps-in turn signaling substantive shifts in commerce and communication. Similarly, the newly installed governments introduced new laws, new bureaucratic practices, and new official languages, continuing and augmenting the modernization processes begun under the Tanzimat, but at much closer quarters and with greater intensity. Finally, and perhaps most notably, the Mandate system imposed hitherto inexistent political borders that were buttressed by import-export restrictions and entry-exit visas. These changes, in turn, impacted tourist travel between citizens of the Mandate territories.

This article uses the growth of interwar tourism from Palestine to Lebanon as a case study for investigating how Mandate-era sociopolitical realities impacted leisure travel. Regional tourism offers new insight into Palestinian-Lebanese relations at a formative moment in the national 
histories of the two communities, providing a view into how each defined itself in relation to the other. The promotion of Lebanon as a summer vacation spot for Palestinians of all ethnic and religious backgrounds illuminates the ways in which the inhabitants of the former Ottoman provinces began understanding their national territory as a brand that could be marketed to their neighbors and not only to foreign residents in the region (or further afield). If the process of establishing national identities, especially for smaller countries, is understood as taking place in conjunction and competition with neighboring states, ${ }^{6}$ then hoteliers and others in the tourism industry promoting Lebanon to Palestinians can be seen as helping to define it distinctly from Palestine, in ways that were different from Lebanese state initiatives to promote Lebanon to European leisure travelers. Tourism was not the only factor in the process of differentiation, but it created new opportunities for external branding and internal self-definition whose regional and relational impact merits recognition. ${ }^{7}$

The discussion here focuses on the 1930s and 1940s, when Mandate realities had taken hold and the new structures defining "Lebanon" and "Palestine" had become more stable and more real to ordinary people. It examines the ways in which Lebanon was marketed to Palestinian vacationers in the local press, considers the Palestinian government's economic interest in facilitating tourism to Lebanon versus tourism to/in Palestine, investigates how religious affiliations were invoked as Lebanon-bound tourism became caught up in Palestinian politics, and considers how Lebanon tourism spurred interest in further developing Palestine's regional tourism industry. (In consequence, this study does not address the tradition of leisure travel to the Levant by Europeans, Americans, and other foreigners. It focuses on Levantines as travelers and tourists within their own region.) The article concludes by suggesting that tourism, with its mixture of private and government sector interests, serves as a prism for the messy process by which "Lebanon" and "Palestine" became defined in relation to, and also partly against, one another. Interwar regional tourism-leisure travel by people of now-different countries within the same geographic region-highlights the process by which two areas, for centuries part of the same empire, struggled to reframe themselves as discrete national entities and how their inhabitants began articulating a relational sense of identity, one distinct from, but connected to, that of their neighbors.

\section{Sources and Approach}

This study lies at the intersection of two historically inflected fields of research, namely those of tourism and of national imagining. Since the early 2000s, both have produced a growing body of scholarship focused on the Middle East. Yet neither field has produced many studies examining the historical roles of regional tourism and of geographic contiguity in forming and defining national identities. This study builds from the ideas of national imagining and the roles that the imaginations of various people in Palestine and Lebanon played in helping define "the national" for each country. Such people came from all walks of life: they could be from religious majority or minority communities, rural farmers or urbanites, members of various ethnic and linguistic communities, from elite families or populous neighborhoods, and included the various British and French government officials working-consciously or unconsciously-to shape national identities according to their own visions for the region. In considering the role of imagination 
alongside the focus on newspaper advertisements, this article draws from the foundational work of Benedict Anderson. ${ }^{8}$ However, given that newspapers in Palestine were read by a minority of the total population, and subdivided by language, Anderson's insights here should be understood as providing a general conceptual frame rather than a specific model.

If national imagining is the first intellectual node of this study, tourism is the second. There have been several notable recent works on tourism in the Middle East, although it remains one of the less-studied topics of twentieth-century Middle Eastern history. Those most relevant to the present discussion include Waleed Hazbun's Beaches, Ruins, Resorts: The Politics of Tourism in the Arab World, which presents case studies of tourism in Tunisia, Jordan, and the United Arab Emirates, followed by Rami Daher's edited collection, Tourism in the Middle East: Continuity, Change, and Transformation. ${ }^{9}$ Hazbun foregrounds the political aspect of tourism, arguing that tourist activity and tourism promotion can never be separated from domestic and international politics. ${ }^{10}$ Yet while two of his case studies focus on what could be considered regional travel-that of Europeans to Tunisia and of Israelis to Jordan-in neither case are the sending and receiving countries part of one former state, as Palestine and Lebanon had been. Israelis are seen by many Jordanians as a distinct other (and vice versa), while Europeans in prerevolution Tunisia enjoyed privileges of wealth as well as exemption from state scrutiny. A third key work, Rebecca L. Stein's Itineraries in Conflict: Israelis, Palestinians, and the Political Lives of Tourism, probes the ways in which Israeli regional tourist practices help reshape Israel's position within the broader Middle East, vis-à-vis both the Palestinian territories and neighboring countries. ${ }^{11}$ Her argument engages deeply with consumption practices and the role of imaginaries in tourism. While the geographic proximity and political interweaving of Israelis and Palestinians does not fully map onto the idea of regional tourism as invoked here, Stein's work helps provide a framework for examining tourism within the Middle East. ${ }^{12}$

This study uses published sources, namely archival government documents, as well as period newspaper articles, advertisements, and promotional materials. Because it focuses on how Lebanon appeared as a branded tourism destination to Palestinians, including the impact of travel to Lebanon on the Palestine government, the study focuses on Palestinian sources. It looks at government documents produced by Mandate officials in Jerusalem, British Foreign and Colonial Office documents created and circulated in London, and Palestinian newspaper articles and advertisements. These materials were obviously crafted for distinctly different audiences and purposes: government documents were directed at an internal, limited, and largely British audience while the newspaper copy, produced by Lebanon-based hoteliers, area transportation companies, and travel agents, was destined to local and literate consumers. Collectively, these sources illuminate the emerging role played by regional tourism in helping shape Lebanon as a distinct national space with leisure appeal for Palestinians, who were treated as neighbors, foreigners, and consumers at one and the same time.

The article focuses on the themes that newspaper advertisements used in appealing to potential Palestinian tourists, branding "Lebanon" in particular ways. ${ }^{13}$ It examines Palestinian newspaper articles on both Lebanese tourism and the competing, and simultaneous, efforts to build a domestic and regional tourism industry for Palestine, taking into consideration the newspapers' own understanding of tourism and its connection to national identity and national pride. Finally, 
it looks at official Mandate and British documents in order to understand governmental interest in Palestinians traveling to Lebanon, specifically, and in Palestinian tourism more generally. The net effect is to build a picture of regional tourism in new, neighboring states that suggests the importance of neighbors in shaping national identities.

\section{Mandate-Era Travel: New Structures, New Logistics}

Palestinians had been traveling to Lebanese towns for vacation long before 1920. Travel from surrounding areas to Lebanon-and particularly to its mountain regions-was a long-standing practice by the start of the Mandate era. But with the 1920s came two key changes in terms of structure and of logistics. A 1919 estimate of Ottoman Mount Lebanon's economy places income from tourism at just over 8 percent of total annual revenues, compared with 42 percent from emigrant remittances and 21 percent from silk production. ${ }^{14}$ At the time, several influential figures advocated for changing these proportions, especially as the silk industry continued to decline from its nineteenth-century peak, and wartime privations due in part to the loss of remittances remained a recent memory. As Lebanon appeared unable to develop a substantive economic base from agriculture or industry, they argued, it should capitalize on its natural tourism resources. In an article on Lebanon's hospitality industry, Fouad al-Khoury argued that the country's future lay in embracing its potential as a "villégiature d'été, une station climatérique" or summer residence destination and health resort, which could also serve as a base for side trips and excursions by "the inhabitants of neighboring towns, those of Syria, Palestine, Anatolia, Egypt, [and] I would even say, for Europe as well." 15 He laid out many of the themes and selling points that would later characterize advertisements for Lebanon tourism: the summer resident (villégiateur) who enjoys the physical beauty of the country with its mountains and light; the ailing, whose health is recovered thanks to the fresh air, salubrious climate, and mineral waters; and the tourist or excursionist, who enjoys the historical interest and "picturesque curiosity" of Lebanon's historic sites. ${ }^{16}$

This notion of Lebanon as a seasonal travel destination, with salutary health benefits in a mountainous, rural atmosphere, seems to have developed somewhat organically from the late nineteenth-century practice of local residents of Beirut and other cities who returned to their family villages for religious holidays or at the end of the school year, allowing them to enjoy the crisp air and cooler temperatures away from the humidity and heat of the coast. ${ }^{17}$ As Bruno Dewailly and Jean-Marc Ovazza argue, such practices formed the foundation of what evolved into istiyaf (summering) and the notion of a summer leisure travel season, whose development into a tourism "sector" the Mandate government and semiprivate regional tourism organizations supported. ${ }^{18}$ Jared McCormick describes the process, during this period and in later Lebanese history, as "creating a season." 19 But how would this newly constructed season fare in a world of equally new borders?

The creation of national borders, separate administrations, tax regimes, and currencies produced a new separation between place of origin and destination that made travel between now-discrete Lebanon and Palestine more complex. Why would Palestinians-not to mention Egyptians or Iraqis-travel to Lebanon if it now required obtaining a visa, changing currency, and interfacing with government officials in a different European language? These difficulties were offset by an 
increasing push to promote leisure travel to Lebanon and by advances in transportation and communications, which allowed vacationers to travel more quickly and cost-effectively than their parents or grandparents had been able to do, thanks to regular train and taxi, car, or bus services. (A 1935 report on "economic conditions in Palestine" noted that a seat in a five-seat taxi going from Jerusalem to Beirut, with a stop in Haifa, took seven hours and cost P£ (Palestine pounds) 4.5. It also noted that Palestine's three railway lines connected to one another and thus to the Haifa station, where passengers could continue on to Lebanon. $)^{20}$

By the late 1920s, Lebanon's tourism sector was expanding and professionalizing. A 1929 American University of Beirut undergraduate thesis in business administration, titled "Lebanon as a Summer Resort," listed several Arabic-language guides published by various Lebanese professional and semigovernmental organizations, including tour agencies (Kawatly and Taweel and Co., for example) and regional tourism organizations (such as Villégiature du Mont-Liban), as well as summer resort brochures published by the Lebanese government. ${ }^{21}$ As Nadya Sbaiti argues, even this nascent industry had already begun segmenting its "tourist publics" into Lebanese, Arab, and European; by the early 1930s, Lebanese tourism as a concept and a practice seems to have been fairly deeply integrated into the social and economic workings of the two Mandate states. ${ }^{22}$ This meant that tourism was now not only a concern for hotel operators and other service providers, but was also becoming one for the two national governments-not to mention municipal governments in the mountain towns that Lebanese hoteliers promoted and in transport hubs like Jaffa. While the governments appear to have concentrated more on the visa and revenue aspects of tourism, private citizens working in the travel sector faced the challenge of convincing Palestinians to come to Lebanon and spend their money there despite the additional hassle of a border crossing and a visa, particularly during the many moments of tension or hostility that flared up in both places during this period. They did so because tourism was profitable, or could be: Fuleihan listed hotel owners, landlords, and farmers selling produce to hotels and restaurants as the top three beneficiaries of summer tourism in Lebanon. ${ }^{23}$ To reach potential clients, they advertised in local newspapers.

The sections that follow look first at Lebanese tourism as presented and promoted in the Palestinian press, focusing on newspaper advertisements and the way their themes helped brand Lebanon. The discussion then explores Palestinian government documents to determine what kind of impact Lebanese tourism had on Palestine's revenues and transportation infrastructure. Finally, looking at both newspaper articles and government memos, the article considers how Lebanese tourism became a spur to Palestinian tourism, suggesting the ways in which tourism and nationalism were becoming intertwined in these two Mandate states. While tourism from beyond the Levant certainly played a role in both countries, the focus on regional tourism-leisure travel by people of neighboring countries within the same geographic region-suggests the importance of regional relationships in the self-defining process of national identities.

\section{Promoting Lebanon as a Vacation Destination}

There were two main ways in which Palestinians were exposed to Lebanese tourism, by word of mouth and via advertising. Word of mouth reports came from friends and family who vacationed in 
Lebanon-or knew someone who had. For Arab Palestinians, these travels may have included visits with relatives or business partners; the imposition of Mandate borders, as is well known, cut across but did not sever long-standing familial and commercial ties. While the record of such visits today is limited to the memories of older Palestinians or mentions in oral histories and memoirs, the practice of vacationing in Lebanon during the Mandate was also driven by word of mouth conveyed in Palestinian newspapers.

Focusing on the travel habits of elite Palestinians was a particular practice of the Palestine Post, whose "Social and Personal" section appeared several times a week. In the month from mid-July through mid-August 1934, for example, the rubric tracked five families who summered in Lebanon: on 19 July, it noted that "Dr. Fuad Dajani, of Jaffa, has left for Lebanon, where he will spend part of the summer"; the following day, it reported that "Mr. Issa Al Issa, owner of Falastin, and his family will leave today for Lebanon, where they are spending the summer"; and on the 30th that "Ahmad Sameh Bey Al Khaldi, Principal of the Government Arab College in Jerusalem, will leave for Lebanon on holiday next week"; in August, it noted, Moghannem Eff[endi] El Moghannem's departure "to Lebanon for a few weeks holiday"; and the return from there of "Izzet bey Nammar, judge of the District Court of Jaffa." ${ }^{24}$ As evidenced by the newspaper's descriptions, these men were all socially prominent, with professional-class jobs as doctors, newspaper publishers, school principals, and judges, among others. Such men would have interacted with and been known to British government officials, as well as English-speaking members of the immigrant Zionist community, and other English-speaking Palestinians who read the Palestine Post. Mention of their travels not only highlighted their elite status, but also connected that status and the ability to take regular summer holidays to vacation in Lebanon. While other travel destinations figured occasionally, Lebanon was the most-frequently mentioned destination for prominent Palestinians' summer travel.

Beyond reading of others' travel in the local press (or, of course, hearing about it directly), Palestinians learned about leisure travel to Lebanon through newspaper advertisements. This study focuses on newspaper advertisements published in three Mandate-era Palestinian papers, the Arabic-language Falastin, which had been appearing since the 1910s, the Englishlanguage Palestine Post, which began publishing in December 1932, and the Arabic-language al-Difa', which followed less than two years later, in April 1934. The three were some of the most influential papers of the mid and later Mandate era. They reflected Palestine's various political perspectives as well as its cultural diversity and had a sizeable number of subscribers, albeit no mass readership. Falastin was published by an Orthodox Christian Arab, al-Difa ${ }^{\text {e }}$ was published by a Sunni Muslim Arab, and the Palestine Post was published by a Jewish immigrant from New York. The three newspapers also had distinct political perspectives: while Falastin and al-Difa ${ }^{\circ}$ both took an Arab Palestinian, anti-Zionist stance, Falastin was less combative. The Palestine Post, which took a broadly Zionist perspective, addressed itself to Palestine's English-speaking audience in general, and was less bellicose than Hebrewlanguage newspapers. (The latter also reported on tourism and travel, publishing various travel-related advertisements, and further research may uncover developments in this regard more specific to the Hebrew press.) 


\section{MANDATE-ERA ADVERTISING}

Advertisements in Mandate-era Palestinian newspapers took up less space than readers familiar with later publishing norms might expect. On most days, each paper published no more than ten advertisements in total-for al-Difa', which had the smallest number in the 1930s, fewer than five ads per issue. Many pages had no advertisements at all, and a page with more than two advertisements was quite unusual, particularly in the Arabic newspapers. Further, their small number meant that travel-related advertisements, particularly during the summer season, were all the more prominent and each individual advertisement was perhaps more eye-catching to readers as a result.

Travel-related advertisements were in many respects crafted in the same vein as advertisements for other goods and services-like shoe polish, radio sets, insurance, and cigarettes-that appeared more frequently in Mandate Palestinian newspapers. Collectively, the ads from this period suggest the demographics of these newspapers' readership, which for the Mandate period as well as earlier decades remains a challenging question. As scholars like Ami Ayalon and Mustafa Kabha have shown, the press in Mandate Palestine was a thriving institution with a growing readership. ${ }^{25}$ Although subject to government censorship, newspapers of all languages, political, and religious affiliations attracted readers with lively discussions of political and social issues in Palestine and abroad. $^{26}$

Yet as was common throughout the region, newspapers in Mandate Palestine did not have mass readership. Although literacy rates increased and living standards improved during the Mandate, Arabic newspapers reached only a minority of the adult Arabic-speaking population. Estimates range, with Nur Masalha suggesting that rural Palestinians enjoyed only a 15 percent literacy rate, and Ayalon citing a 1931 census that put Muslim male literacy at 25 percent. $^{27}$ Readership rates among the Yishuv were higher, although distributed across several publication languages. Overall, circulation statistics appear low relative to the size of the population: in 1946, near the end of the Mandate, a government survey put the circulation of two major newspapers, Falastin and the Palestine Post, at 8,000 and 20,000, out of a population of roughly 1.9 million. Palestinian newspapers formed a public sphere, but one that favored the prosperous, the literate, and the urban-even with the group reading practices that helped broaden each paper's reach to less-prosperous, partly literate, and/or rural audiences. Newspaper advertisements pointed to these reader demographics by offering primarily imported, relatively high-cost goods and services affordable only to those with middle- or upper-middle-class incomes. Travel advertisements fit this profile, with advertisements for liners to Europe and further afield, the occasional airplane advertisement in the 1940s, and many, many advertisements for Lebanon and its summer hotels.

\section{LEBANON TRAVEL ADVERTISEMENT THEMES}

Lebanon-related travel advertisements stood out from other 1930s-40s Arabic newspaper advertisements because they were so highly evocative. Not all these advertisements had images, but even the all-text ads worked to convey the experience of a Lebanon holiday, rather than simply selling hotel rooms, train tickets, or other concrete goods and services. Broadly speaking, the ads focused on two themes, health and modern comforts, suggesting that these provided 
meaningful benefits to travelers. While health appeared as a theme in both advertisements promoting Lebanon in general and also in advertisements promoting particular hotels or travel packages, modern comforts appeared only in advertisements for particular hotels and packages. Nonetheless, both themes contributed to an overall image of Lebanon as a healthy, relaxing, and modern destination—an image reinforced by each advertisement in its turn.

\section{Health}

Lebanon-related travel advertisements used the words "health" and "healthy," as well as associated terms like relaxation and freshness, over and over. They evoked health through descriptions of Lebanon's salubrious mountain air, offers of health cures, promises of fresh food, and visions of opportunities to rest and relax. Lebanon's mountains were described as "health-giving," offering "vivifying freshness" and "rejuvenating sunshine." 28 Some ads touted, "The rustic LEBANON with its many natural gifts, offers your children the best of good health. Don't lose this splendid opportunity. Take them to LEBANON this summer!" ${ }^{29}$ The words "air" and "health" appeared over and over again: "Regain your health in the Lebanon," said one, promising "fresh air" along with "sport" and "entertainment," ${ }^{30}$ suggesting a broadly healthy experience. An advertorial run in the Palestine Post in June 1935 focused entirely on health, from its title, "Lebanon: A Source of Health" to its claim that "no other resort in the world ... offers so much towards the restoring of good health as does the Lebanon." The advertorial cited Lebanon's "health-giving springs, good food, pure air and splendid climate," and closed with a supportive quote from someone identified as "President of the Egyptian Doctors Mission," who promised that no one could "continue to be ill" in the Lebanese mountains. ${ }^{31}$

Health-focused advertisements often included images, some with children, depicting mountains, the cedars, and running streams. One series of ads, which ran with the tagline "This is what you'll see in Lebanon in the summer," blended line drawings of picturesque scenery with brief but evocative text. Some were all-Arabic while others included English-language text, as in the July 1935 al-Difa' ad whose headline stated "Fi jibal Lubnan" (In the mountains of Lebanon) in Arabic and "Lebanon" in English. ${ }^{32}$ While some travel-related advertisements promoted specific resorts or particular travel agencies, othersespecially those of the "This Is What You'll See" series-promoted Lebanon in general. (These advertisements did not identify their creator but appear to have been produced by an organization calling itself the Association for the Promotion of

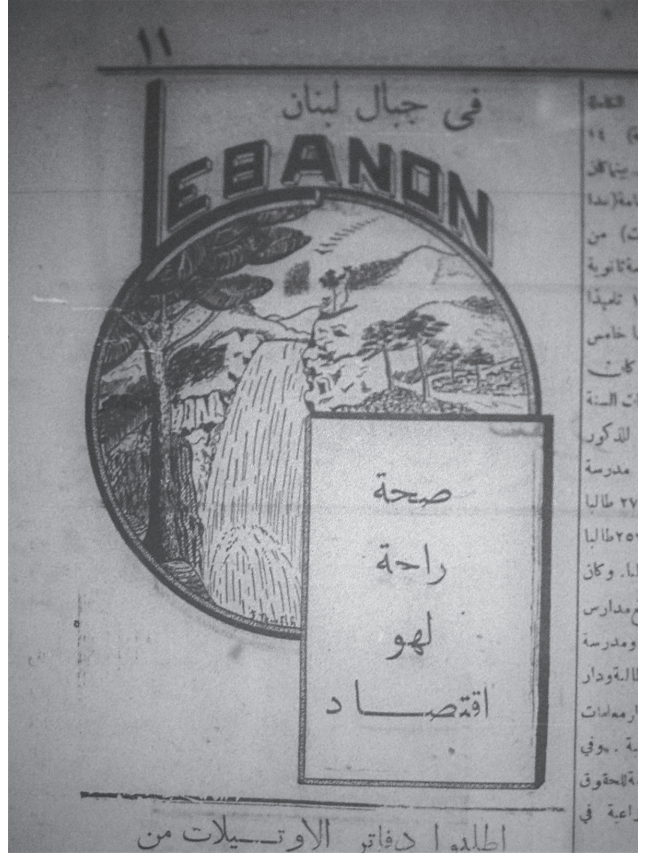

"In the mountains of Lebanon," Al Difa', 1 July 1935, p. 11. (Columbia University microfilm collection) 
Tourism and Istiyaf, whose name figures on the 1937 ads, or its precursor.) Collectively, they constructed an image of Lebanon that included fresh air, pristine waters, good food, a temperate climate, and an active but relaxed lifestyle.

\section{Modern Comforts}

The healthy lifestyle that these travel advertisements presented as characteristically Lebanese was an enticing one. Modern comforts also played an important role in these promotional materials, particularly in ads for specific hotels or resorts. Hotel ads generally listed the comforts that each offered: tennis courts, indoor plumbing, a dance hall, gourmet meals, an in-house orchestra, telephones, and so on. They said things like "Good catering, diets to suit guests. Hot and cold water in rooms. Tennis." 33 Some combined the two themes, like a hotel in Zahle, which promised a "grand healthful building, composed of 120 rooms, running water, bath rooms, tennis court, orchestra, radio, cinema, dance hall, gardens, American bar, excellent kitchen, large hall, casino, [and] telephone." ${ }^{34}$ These lists shed light on what hotel proprietors in the 1930s considered selling points, suggesting that modern comforts included entertainment like dancing as well as the latest audiovisual technology.

While conveying distinct messages, the two themes formed a complementary portrait of Lebanon as a brand and as a travel experience. Lebanon was presented in these advertisements as healthy and modern-relaxed and picturesque yet closely connected to the modern-day world. It offered visitors a sporty lifestyle along with

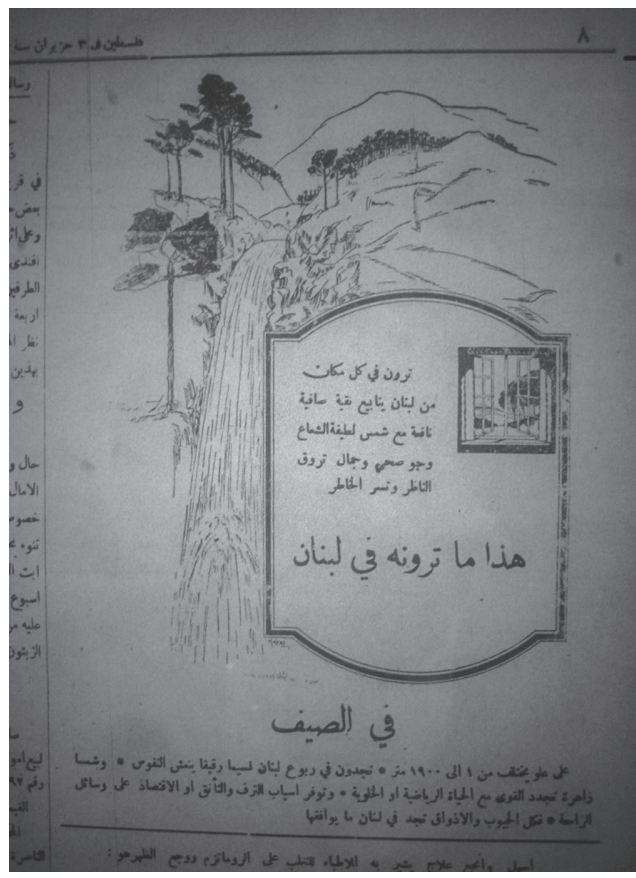

"This is what you'll see in Lebanon in the summer," Falastin, 3 June 1933, p. 8. (Columbia University microfilm collection) sophisticated evening entertainment and, as the ads promised, remained "economical." Perhaps most suggestively, these themes collectively implied that healthy modernity lay outside urban areas, in the mountains where trees and fresh air were plentiful. None of these advertisements so much as mentioned Beirut.

\section{Other Travel Advertisements}

In the 1930s, Lebanon was the only Middle Eastern destination advertised regularly in the Arabic press in Palestine. There were no similar advertisements for summer travel to Egypt, Turkey, or any other Middle Eastern location, with the exception of a few advertisements for bus travel to Egypt in the 1940s. ${ }^{35}$ However, the Palestinian papers frequently published ads for European and North/South American travel. A brief examination of these helps 
contextualize the Lebanon travel advertisements while highlighting their distinctiveness. Ads for European and American travel destinations focused entirely on transportation, promoting international steamships and/or travel companies like Wagon-Lits Cook, the Lloyd Triestino (an Italian shipping steamship), and the French-owned Messageries Maritimes. The fundamental selling points were frequency of departure, cost, and speed of travel, as for example a 1933 Greek steamship company that advertised "17 days from Haifa to New York." 36 Further, regional stops like Beirut appeared to be supplemental rather than the focus of travel, as with a 1936 Palestine Maritime Lloyd brochure that advertised itself as the first Palestine line between Haifa and Constantza (Romania, via Istanbul) with the fast steamers Har Zion and Har Carmel for passengers and cargo, with optional calls at Istanbul, Tripoli, Beirut, and Famagusta. ${ }^{37}$ On the timetable, which ran from October 1936 through January 1937, "Cyprus, Tripoli, or Beyrouth" were listed together in one slot, with the implication that the ship might stop at one of them along the way. Further, one could purchase only a one-way ticket to Beirut-not a round trip (allerretour) - and no prices were listed for Tripoli or ports in Cyprus. These ports were incidental, not integral to the route.

Further, advertisements for European or American travels were limited to transportation. There were no ads for hotels in France, for example, nor for package tours that emphasized the climate of Italy or the bustle of New York. As the Palestine Maritime Lloyd timetable and the advertisements suggest, international travel promotions focused on the mechanics of transport, not on evoking a travel experience. They seem to have addressed customers who had already decided to travel, likely for more pragmatic purposes, and were concerned with selling these customers on cost, speed, and convenience rather than leisure. Yet such advertisements help flesh out the broader picture of travel in this period, indicating that Palestinians were traveling globally as well as regionally. The focus on transportation rather than experience, along with the absence of any American or European hotel advertisements, reaffirms the greater importance of Lebanon as a leisure destination for Palestinians than Europe or the Americas.

\section{Lebanese Government Support}

How important was tourism to Lebanon's economy-and how important were Palestinian tourists? In terms of numbers, the tourist trade from Palestine to Lebanon was substantive for the area, as well as for each country. The Palestine Government's 1931 census estimated Palestine's population at just over 1,000,000; the 1932 Lebanon census described its population as just over $650,000 .^{38}$ In 1934, a Lebanese estimate put the number of tourists coming from Palestine as averaging 1,500-2,000 per week during the summer, or between 18,000 and 24,000 for the three summer months. ${ }^{39}$ (This estimate may have included Egyptians and Iraqis transiting through Palestine, rather than Palestinian citizens per se.) Hence, some 1.8-2.4 percent of Palestine's population visited Lebanon each summer, boosting Lebanon's total population by $2.8-3.7$ percent during that season.

Palestinian newspaper articles published in the early and mid-1930s suggested that tourism from Palestine was important enough for the Lebanese Mandate government to support private sector efforts. For example, a December 1932 article in the Palestine Post, titled "Civic Improvements in 
the Lebanon: Scheme to Attract Tourists," listed "appropriations for public improvements" recently allocated to towns throughout Lebanon by the Council for the Development of Travel in the Lebanon, such as the S£ (Syrian lira) 4,000 given to the town of Tannourine to construct a public garden. Other allocations supported similar projects, as well infrastructural improvements to build roads, improve the water supply, and extend the electric grid. While such improvements clearly benefited Lebanese citizens, it was notable that they were funded by the government's tourism council rather than a utility or public works bureau. ${ }^{40}$ At times, the Lebanese Mandate government supported tourism by offering financial incentives to travelers, like reduced entrance visa fees during the summer season. In April 1935, the Palestine Post reported an 80 percent such discount on tourist visas-from 650 mils to 130 mils-as a means to encourage regional tourism. ${ }^{41}$ Further, Lebanon experimented with promoting tourism through contests such as a 1935 "snapshot contest for all Palestinians summering" there that invited photographs "characteristic of the Lebanon" and offered S£ 75 to the winner. ${ }^{42}$ Submissions were to be sent to the "Palestine Agency for Advertising the Lebanon" via an advertising agency with offices in Tel Aviv and Beirut.

Palestinian press coverage of Lebanese government support for tourism initiatives seems to have spurred the newspapers to advocate for greater development of Palestine's own tourism industry. The Palestine Post in particular tracked Lebanon's private and governmental initiatives to support Lebanon tourism, emphasizing in one article after another the number of travelers to Lebanon coming from Palestine. Keeping more Palestinians in Palestine, and encouraging Egyptians and other transit travelers to stay longer, would benefit Palestine's economy, the Post argued, although the government in Palestine seemed more inclined to see benefits in encouraging travel to Lebanon.

\section{Mandate Palestine Government Interest}

The Lebanese government's interest in encouraging regional tourism is understandable; what might be more surprising was the Mandate Palestine government's interest in encouraging travel to Lebanon, which could have been considered a revenue loss. But for the Mandate government, travel to Lebanon-whether business or leisure, and particularly during the summer seasonresulted in increased train ticket revenues. It also provided ancillary revenues from entry or transit, as well as the general economic benefit accruing from travelers' meals and hotel stays while en route. This was the case because tourists going to Lebanon from Egypt (and, to a lesser degree, from Iraq) often traveled by train, which necessitated traveling through Palestine and on its railways. The train was fast, reliable, and-thanks to second- and third-class carriage optionsinexpensive. ${ }^{43}$ As a result, the Palestine government saw benefits from Lebanese tourism, even if Egyptian tourists heading to Lebanon were merely transit visitors in Palestine, for whom the railways ran "special trains" during the summer. ${ }^{44}$ An increase in the number of second- and third-class train travelers from Egypt to Lebanon between the summers of 1930 and 1931, for example, yielded a revenue increase of just over P£ 600-not a huge sum, but a "satisfactory" amount from the government's perspective. ${ }^{45}$ 
In 1930, the Palestine Railways Administration counted the number of summer travelers going through Palestine from Egypt en route to Lebanon at 6,316 total-808 in first class, 3,412 in second class, and 2,096 in third class. For 1931, the numbers increased nearly 15 percent, to 7,232 (718 passengers in first class, 3,881 in second, and 2,633 in third). ${ }^{46}$ By 1932, the numbers had declined slightly, to a total of 6,929 , which the Railways Administration attributed to "increased competition of road services at very low rates," particularly interstate bus services. In other words, the lower numbers did not mean that fewer Palestinians were traveling to Lebanon, but that travelers now had more transportation options. ${ }^{47}$ Whatever their mode of travel, they remained an important revenue source for the Palestine government.

Their importance can be seen from the government's efforts to encourage transit travel. In 1930, these included "special through-booking arrangements, including reduced fares and a contract motor service between Haifa and Beirut." 48 Such arrangements were designed to make it possible for transit passengers to book their entire journey at once, rather than traveling on one ticket to Palestine and booking the second leg to Lebanon from Jerusalem or Jaffa. The government also approved a plan to provide free or reduced-price train tickets to "tourist agents." ${ }^{\text {" Similar }}$ initiatives in later years, including expanded train service and reduced fees, provide further evidence that the Palestine Mandate government not only profited from tourism to Lebanon from or through Palestine, but also worked to facilitate travel to Lebanon. At the same time, however, officials increasingly looked to private sector initiatives to develop tourism within Palestine, particularly that originating in Europe or further afield, as with the steamship companies mentioned above.

\section{Promoting Palestine}

Like Lebanon, Palestine had long been a tourist destination, although in a more religious vein for observant Christians, Jews, and Muslims for whom Jerusalem was a pilgrimage site. In the late 1800s, Palestine as a religious tourism destination enjoyed a resurgence among Europeans and Americans, if not for actual pilgrimages, then for sight-seeing locations mentioned in the Bible. As Kobi Cohen-Hattab has noted, tourism in Palestine became another arena for the Yishuv's battle over Palestine. Cohen-Hattab argues that Zionists saw tourism as a "political weapon" which, if wielded effectively, would convince tourists to support the Zionist cause, turning them into advocates for Zionism with British Mandate officials and once back in their home countries. ${ }^{50}$ While the success of this approach is difficult to quantify, Cohen-Hattab's work points to the political saliency of tourism, and to the international focus of Palestinian tourism scholarship.

The Palestine Mandate government also focused on international tourism from Europe and other places beyond the Middle East. In his 1930 annual report, the Railways' general manager noted that Palestine would soon be attracting more tourists with the addition of two "large and excellent hotels" in Jerusalem and the alteration of another "fully to meet modern requirements in the way of comfort." ${ }^{\text {"1 }}$ The report cited the lack of hotels as the reason why "more people, especially wealthy people, did not come to Palestine and why those who came did not stay for longer periods." While the Mandate government did less to facilitate international tourism than 
regional transit travel, it did help arrange special train services for cruiser steamships and other large passenger groups arriving by boat.

An increasing number of local initiatives worked to keep Palestinians vacationing at home. In May 1932, for example, Falastin noted that the "Palestinian Society for Encouraging Tourism" was holding a tea party "to encourage a tourist season in this country, [since tourism] is among its greatest resources." 52 Although accounts of grassroots efforts like these appear only intermittently in the press, they suggest that Palestine's tourism potential was of interest to many Palestinians. But if Lebanon offered health and modernity, what did Palestine offer? In 1934, a Palestine Post article titled "Jerusalem v. the Lebanon" reported on plans for several new Jerusalem hotels, highlighting the city's historic and religious sites, in contrast with the fresh air and mountain scenery of rural Lebanon. Further, the article argued, the challenge for Palestine tourism was not attracting foreigners but persuading residents to holiday at home. "It is hoped that with the provision of better accommodations," the article concluded, "Palestinians will not have to go across the border in order to enjoy a cool holiday or a rest." ${ }^{" 53}$ But shaking the allure of Lebanon seems to have been difficult, even for Palestinian hotels: the Grand Orient Hotel in Jaffa, for example, advertised that its restaurant featured a "Beiruti chef." 54

As the 1930s wore on, the impulse toward domestic tourism seems to have become increasingly intertwined with political concerns. Domestic tourism projects received an unexpected boost in April 1936, when the general strike that marked the beginning of the Arab Revolt disrupted summer and other holiday travel plans. Limited train and car services exacerbated the situation, for both Palestinians and transit passengers. According to a government report, "train services were considerably restricted," leading to "little organized tourist traffic, [while] the annual summer traffic from Egypt to the Lebanon almost disappeared with the deterioration of the security situation." 55 As in other areas of social and economic life in Palestine, the Arab Revolt sparked a shift in Palestinian leisure travel to Lebanon.

Still, efforts to promote tourism in Lebanon continued although their reception in Palestineparticularly among those who followed the Palestine Post-began to change. In April 1938, the Post began publishing a mixture of editorials and letters to the editor proposing that Palestinian Jews observe a travel boycott. The Post had often noted that many Palestinian travelers to Lebanon were Jewish, going so far as to publish a headline in 1934 that read, "Palestinians Invade the Lebanon/Jews Are Majority among Holiday-Makers." ${ }^{156}$ In 1937, it praised "the people of Lebanon" for publishing a guidebook to the country in modern Hebrew. ${ }^{57}$ But as the revolt continued and Haj Amin al-Husseini took up residence in Lebanon, more negative feelings surfaced. Arguing that Lebanon's support for Palestinian rebels was aiding the revolt, one letter to the editor suggested that, "A complete boycott of all Syrian and Lebanese exports would bring home to our neighbors that it is in their own interest to help keep peace in Palestine." It further specified that "even more effective would be a boycott of Syria and Lebanon as holiday resorts." 58 In June, the paper noted that Beirut's L'Orient had recently discussed "the dangers of a boycott of Lebanese summer resorts and merchandise," and the Post expressed hope that this would shift Lebanese opinion. ${ }^{59}$ The Post also cited the Hebrew-language Davar as stating that Lebanon's summer resorts and hotels were "empty," leading "hotel keepers [to] bitterly complain" against the alienation of Jewish Palestinians. ${ }^{60}$ 
It is difficult to assess how empty the hotel rooms were, and how long-term an impact a travel boycott might have had, partly because proposing boycotts was the order of the day. After July, the issue faded from the Palestine Post's pages; in December, the paper published an article praising the skiing in Lebanon, and the following summer, travel advertisements resumed. Neither Falastin nor al-Difa focused on Jewish Palestinians as the primary Lebanon vacationers from Palestine. (Interestingly, a few businesses promoted themselves as having personal connections to Palestine. Bihar Restaurant and Hotel in 1937 advertised itself as a "Palestinian restaurant in Lebanon's summer residence." It noted that the owners were the same Palestinian family who owned the Victoria Restaurant in Haifa. ${ }^{61}$ ) Some articles reported lower numbers of tourists for the 1939 summer, while others suggested that these held steady. What did seem to have a definitive impact was the lead-up to the outbreak of World War II at the end of August. Lebanon replaced discounted visas with tightened entry requirements: in 1940, those wishing to spend the summer in Lebanon were told to submit their applications by May 25. ${ }^{62}$ With fuel rationing and other restrictions, Lebanon tourism suffered during the war. While travel-related advertising began reappearing in 1943, the complications continued. New restrictions requiring health certificates for anyone entering Lebanon from Jaffa and Haifa, instituted in September 1944, presented challenges to hotelier and traveler alike. ${ }^{63}$ The end of the war in May 1945 seems to have spurred some new tourism efforts, as with the Beit Meri Grand Hotel, which advertised its June 15 opening multiple times in Falastin. ${ }^{64}$ But the audience pool had narrowed: in 1946, it was reported that the Lebanese government had banned visas for Palestinian Jews. Whether by choice or by fiat, the bulk of Palestinians traveling to Lebanon for holidays were now Arab.

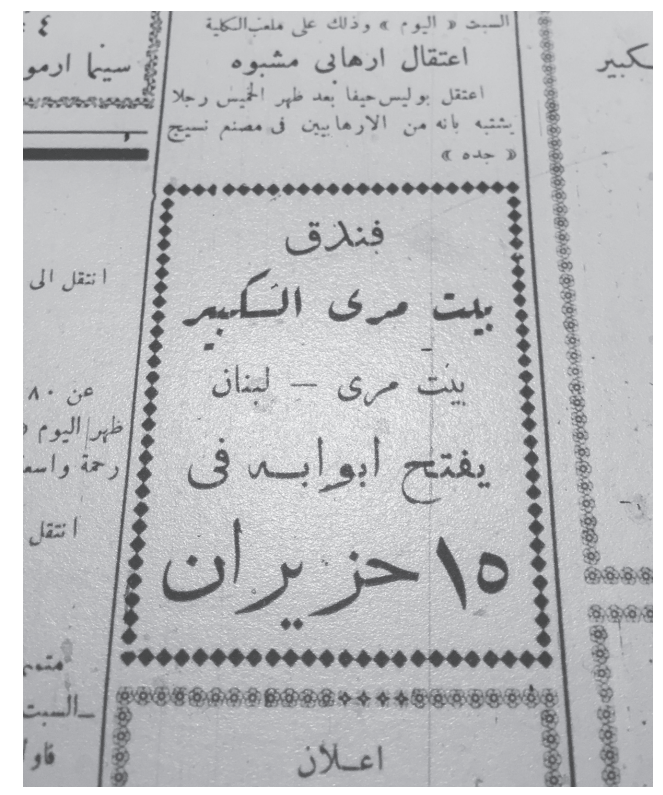

Beit Meri Grand Hotel, Lebanon, advertisement, Falastin, 9 June 1945, p. 4. (American University of Beirut microfilm collection) 
Advertisements for Lebanon's hotels continued to appear in Falastin through the summer of 1947: the Villa Karam in Broummana and a hotel in Bhamdoun were advertising as late as June, with the latter promising "crisp air," excellent food, and "moderate prices." ${ }^{65}$ By 1948 , the newspaper had shrunk to a four-page broadside with three or four advertisements of any kind. Its last issue for the year was Saturday, 24 April 1948, which was too soon for any kind of summer season advertising. When Falastin resumed publishing in February 1949, it did so from Jordan. The Mandate had ended, and with it the possibilities for easy, vacation-style travel from Palestine to Lebanon. While Lebanon's hoteliers searched for new markets, the relational national imaginings between Lebanon and Israel took on new and much more hostile contours.

Yet the impact of the Mandate era should not be discounted. For approximately twenty years, hoteliers and the growing tourism industry marketed Lebanon to Palestinians as their "ideal" summer holiday destination, and as "Palestine's summer residence." In doing so, they portrayed Lebanon as healthful, relaxing, and modern, with mountain air and American bars, running brooks, and in-house orchestras. Lebanon offered a summer retreat for the entire family, at reasonable prices. If Palestine by reflection looked dusty, flat, and hot, Palestinians appeared as sensible money managers with a love of family, who appreciated and were accustomed to modern conveniences like telephones and hot running water. The travel-related advertisements supported two sets of national imaginings-the Palestinian and the Lebanese-with distinct but connected elements. They help illuminate the process of national imagining as a relational one, in which neighboring countries can also play an important role.

\section{About the Author}

Andrea L. Stanton is associate professor of Islamic studies and an affiliate faculty member at the Center for Middle East Studies, University of Denver. Her first book, "This Is Jerusalem Calling": State Radio in Mandate Palestine, was published by the University of Texas Press in 2014.

\section{ENDNOTES}

1 An early version of this article was presented at the 2009 Middle East Studies Association (MESA) Annual Meeting in Boston, with related presentations at the American University of Beirut in February 2015 and at the November 2015 MESA Annual Meeting in Denver. Thanks to all panelists and discussants for their thoughtful comments, especially Waleed Hazbun, Nadya Sbaiti, and Tsolin Nalbantian, as well as JPS reviewers. My most sincere appreciation to Maia Tabet, who gave this article its final and most thoughtful read. All errors are my own fault.

2 Hotel Petra Haifa advertisement, Falastin, 9 June 1935, p. 7.

3 Grand Hotel Kadri advertisement, Falastin, 22 May 1935, p. 3; 2 June 1935, p. 11. All translations are my own.

4 "Lebanon: Palestine's summer residence," advertisement, Falastin, 20 June 1935 (and other dates), p. 7.

5 "Lebanon, Palestine's summer residence: Relaxation, health, economy," advertisement, Falastin, 13 July 1935, p. 3.

6 There is room for future work on a related issue: namely, the issuing of Palestinian passports, which began being printed in 1926, and their sociopolitical impact. The Mandate government reported in 1934 that approximately 50,000 had been issued to date, with 21,249 applications for passports and return visas (for foreign passport holders resident in Palestine) that year. The numbers increased dramatically in subsequent years: 36,055 applications in 1935, 34,689 in 1936, 46,798 in 1937, and 
Locating Palestine's Summer Residence: Mandate Tourism and National Identity

40,324 in 1938. See Palestine Sessional Papers: Administration Reports, Department of Migration, series CO 814, The National Archives (TNA), London, for individual years.

7 This study focuses on Lebanon because the advertisements speak of Lebanon. There are no separate advertisements for travel to Syria in the 1930s and 1940s. Places like Bloudane are included in package tours, as part of travel to and in Lebanon.

8 Benedict Anderson, Imagined Communities: Reflections on the Origin and Spread of Nationalism (New York: Verso Books, 1983).

9 Rami Farouk Daher, ed., Tourism in the Middle East: Continuity, Change and Transformation (Clevedon, UK: Channel View Publications, 2006).

10 Waleed Hazbun, Beaches, Ruins, Resorts: The Politics of Tourism in the Arab World (Minneapolis: University of Minnesota Press, 2008).

11 Rebecca L. Stein, Itineraries in Conflict: Israelis, Palestinians, and the Political Lives of Tourism (Durham, NC: Duke University Press, 2008). See also her earlier chapter, '"First Contact' and Other Israeli Fictions: Tourism, Globalization, and the Middle East Peace Process," in Palestine, Israel, and the Politics of Popular Culture, ed. Rebecca L. Stein and Ted Swedenburg (Durham, NC: Duke University Press, 2005). Other studies of interest include Shaul Kelner's Tours That Bind: Diaspora, Pilgrimage, and Israeli Birthright Tourism (New York: New York University Press, 2010).

12 While geographically somewhat further afield, Brian L. McLaren's Architecture and Tourism in Italian Colonial Libya: An Ambivalent Modernism (Seattle: University of Washington Press, 2006) is also useful, although more focused on Italian and foreign travel to colonial Libya.

13 Nation branding is a more contemporary practice that, as Nadia Kaneva notes, operates as a management tool to provide new technologies of governance, giving the national state apparatus more control over the shape, direction, and presentation of the state. What the Lebanon case suggests is a more preliminary experiment in presenting a particular version of the nation-state for an external, consuming market-in this case, regional tourists. See Kaneva, "The Branded National Imagination and Its Limits: Insights from the Post-Socialist Experience," Strategic Review for Southern Africa 39, no. 1 (2017): pp. 116-38.

14 Ottoman Mount Lebanon, a governorate created after the 1860 civil conflict, was a smaller territory than Mandate Lebanon. Marwan Buheiry, "Beirut's Role in the Political Economy of the French Mandate: 1919-39," Papers on Lebanon, vol. 4 (Oxford: Center for Lebanese Studies, 1986); quotes from Albert Naccache's 1919 article "Notre avenir économique" (Our economic future).

15 Fouad al-Khoury, "L'industrie hôtelière au Liban," La Revue Phénicienne, owning director Charles Corm (Beirut: Editions Dar An-Nahar/Editions de la Revue Phénicienne, 1919), p. 37. (Buheiry mentions this article as well: see "Beirut's Role," pp. 5-6.)

16 Al-Khoury, "L'industrie hôtelière au Liban," p. 38.

17 Bruno Dewailly and Jean-Marc Ovazza, "Le tourisme au Liban: Quand l'action ne fait plus système," in Tourisme des nationaux, tourisme des étrangers: Quelles articulations en Mediterranée?, ed. Mohamed Berriane (Florence: Institut Universitaire Européen de Florence, 2004).

18 Dewailly and Ovazza, "Le tourisme au Liban," p. 2. See also Zeina Maasri, "Troubled Geography: Imagining Lebanon in 1960s Tourist Promotion," in Designing Worlds: National Design Histories in an Age of Globalization, ed. Kjetil Fallan and Grace Lees-Maffei (New York: Berghahn Books, 2016), pp. $125-40$.

19 See Jared McCormick, "The Creation of a Season: Sensuality, Sensibilities, and the 'Summer' in Lebanese Tourism," talk delivered at the American University of Beirut, 24 February 2016.

20 C. Empson, Economic Conditions in Palestine, July 1935 (London: His Majesty's Stationery Office, 1935), p. ix for the taxi reference, and p. 69 for the railway lines. Empson is identified in the report as a "British commercial agent" working in Haifa.

21 Farid Amin Fuleihan, "Lebanon as a Summer Resort" (BA thesis, Department of Business Administration, American University of Beirut, 1929), https://scholarworks.aub.edu.lb/. 
22 See Nadya Sbaiti, "Land, Tourism, and Pageantry in 1930s Lebanon," (paper presented at the 2015 MESA Annual Meeting, Denver, CO, November 2015).

23 Fuleihan, "Lebanon as a Summer Resort," pp. 15-16.

24 "Social and Personal," Palestine Post, 19 July 1934, p. 5; 20 July 1934, p. 5; 20 August 1934, p. 5; and 24 August 1934, p. 5. Note: The Post's copyediting standards were erratic: sometimes, it used the spelling Khaldi, and at others the now standard Khalidi; similarly, Ahmed was spelled with an " $\mathrm{e}$ " at times and with an "a" at others.

25 See, for example, Ami Ayalon, Reading Palestine: Printing and Literacy, 1900-1948 (Austin: University of Texas Press, 2004) and Mustafa Kabha, The Palestinian Press as Shaper of Public Opinion, 19291939: Writing Up a Storm (Portland, OR: Mitchell Valentine, 2007). For a broader study of the Arabic press in the context of printing, see Ami Ayalon, The Arabic Print Revolution: Cultural Production and Mass Readership (Cambridge, UK: Cambridge University Press, 2016).

26 See A Survey of Palestine, vol. 3 (Jerusalem: Government Printer, 1946), Section 15: List of Newspapers Published in Palestine, pp. 1346-55.

27 See Nur Masalha, The Palestine Nakba: Decolonising History, Narrating the Subaltern, Reclaiming Memory (London: Zed Books, 2012), p. 213; Ayalon, Reading Palestine, pp. 16-17.

28 Advertisement, Palestine Post, 6 May 1934, p. 5.

29 Advertisement, Palestine Post, 18 May 1934, p. 7.

30 Advertisement, Palestine Post, 5 June 1935, p. 3.

31 "Lebanon: A Source of Health," Palestine Post, 6 June 1935, p. 15.

32 Advertisement, al-Difa', 1 July 1935, p. 11, and numerous other instances. For the accompanying text, see advertisement, Falastin, 3 June 1933, p. 8.

33 Advertisement, Palestine Post, 4 May 1937, p. 6.

34 Advertisement, Palestine Post, 19 June 1935, p. 3. The American bar description seems to refer to the bar design and layout, and appears to have been a selling point for hotels. The Grand Restaurant Ramallah also advertised itself as having an American bar, although at a later point. See Grand Restaurant Ramallah advertisement, Falastin, 31 May 1947, p. 4.

35 See for example "Egypt welcomes you and the visa is ready," Falastin, 16 August 1947, p. 4.

36 Advertisement, Falastin, 14 June 1933, p. 2.

37 Palestine Maritime Lloyd timetable (Haifa: E. Marcus, 1936), private collection. As a Palestine-based ship company with a Zionist outlook, Palestine Maritime Lloyd may have been slightly atypical compared with other shipping companies active in Palestine. In 1935 it was described in the Jewish Daily Bulletin as having "Jewish crews" and flying the Mandate Palestine flag. See "New Ship Links Palestine and Rumania Ports," Jewish Daily Bulletin, 7 March 1935, p. 3.

38 The 1931 census put Palestine's total population at 1,033,314. See Edward Hagopian and A. B. Zahlan, "Palestine's Arab Population: The Demography of the Palestinians," JPS 3, no. 4 (1974): pp. 32-73. Lebanon's 1932 census put its total population at 652,012. See Kais Firro, Inventing Lebanon: Nationalism and the State under the Mandate (London: I.B.Tauris, 2003), p. 121.

39 "How Palestine Is Helping the Lebanon," Palestine Post, 5 September 1934, p. 7. The article cites a Beirut newspaper as the source for these numbers.

40 "Civic Improvements in the Lebanon - Scheme to Attract Tourists," Palestine Post, 26 December 1932, p. 2.

41 "Syrian Summer Visas," Palestine Post, 23 April 1935, p. 6. The mil was equivalent to 1/1000 lira.

42 "Snapshot Contest for All Palestinians Summering in the Lebanon," Palestine Post, 1 July 1935, p. 3.

43 TNA CO 814/4-0010 Palestine Sessional Papers: Administration Reports - Report of the General Manager on the Administration of the Railways, 1930.

44 For example, in 1933-34, there were eighteen special trains. In 1934-35, there were twenty-one. See TNA CO 814/8-0012 Palestine Sessional Papers: Administration Reports - Report of the General 
Locating Palestine's Summer Residence: Mandate Tourism and National Identity

Manager on the Administration of the Railways, 1933-4 and TNA CO 814/9-0014 Palestine Sessional Papers: Administration Reports - Report of the General Manager on the Administration of the Railways, 1934-5.

45 The exact increase was from P£ 9,081 to P£ 9,695. TNA CO 814/50005 Palestine Sessional Papers: Administration Reports - Report of the General Manager on the Administration of the Railways, 1931.

46 TNA CO 814/50005.

47 TNA CO 814/7-0006 Palestine Sessional Papers: Administration Reports - Report of the General Manager on the Administration of the Railways, 1932-3.

48 TNA CO 814/7-0006.

49 TNA CO 814/26 Palestine Sessional Papers: Executive Council Minutes - Executive Council Decisions, 1930.

50 Kobi Cohen-Hattab, "Zionism, Tourism, and the Battle for Palestine: Tourism as a PoliticalPropaganda Tool," Israel Studies 9, no. 1 (2004): pp. 61-85. See also Kobi Cohen-Hattab and Yossi Katz, "The Attraction of Palestine: Tourism in the Years 1850-1948," Journal of Historical Geography, 27, no. 2 (2001): pp. 166-77, in which the authors highlight the Mandate era as a distinct period for tourism development in Palestine.

51 TNA CO 814/4-0010 Palestine Sessional Papers: Administration Reports - Report of the General Manager on the Administration of the Railways, 1930.

52 "Party by the Palestinian Society for Encouraging Tourism," Falastin, 5 May 1932, p. 5.

53 "Jerusalem v. the Lebanon," Palestine Post, 15 October 1934, p. 2.

54 "New establishment in Jaffa," advertisement, Falastin, 4 June 1933, p. 2.

55 TNA CO 814/13-0013 Palestine Sessional Papers: Administration Reports - Report by the Treasurer on the Financial Transactions, 1938-9.

56 "Palestinians Invade the Lebanon," Palestine Post, 29 August 1934, p. 2.

57 "Reflections," Palestine Post, 7 June 1937, p. 4.

58 Letter, Palestine Post, 21 April 1938, p. 8.

59 "The Lebanon Takes Stock," Palestine Post, 1 June 1938, p. 2.

60 "Fewer Jews, More Political Exiles," Palestine Post, 1 July 1938, p. 7.

61 "Bihar Restaurant Aley Lebanon," advertisement, Falastin, 1 July 1937, p. 3; 8 July 1937, p. 4.

62 "Notice," Palestine Post, 17 May 1940, p. 4.

63 "Anti-Plague Measures in Lebanon," Palestine Post, 13 September 1944, p. 3.

64 See, for example, "Grand Hotel Beit Meri" advertisements in Falastin, 9 June and 22 June 1945, p. 2.

65 Villa Karam advertisement and Hotel Shakif advertisement, Falastin, 28 June 1947, pp. 3, 4. 